\title{
Sosialisasi Akibat Hukum Perkawian Siri Di Kelurahan Sekip Kecamatan Lima Puluh Pekanbaru
}

\author{
Irawan Harahap ${ }^{1}$, Yalid ${ }^{2}$, Riantika Pratiwi ${ }^{3}$ \\ 1,2,3 Program Studi Ilmu Hukum, Fakultas Hukum, Universitas Lancang Kuning, Indonesia \\ e-mail: irawan.harahap@unilak.ac.id ${ }^{1}$, yalid@unilak.ac.id² ${ }^{2}$ riantika@unilak.ac.id ${ }^{3}$
}

\begin{abstract}
Abstrak
Analisis situasi mitra mengambarkan fenomena di masyarakat banyak yang tidak memahami akibat hukum perkawinan siri. Begitu juga dengan masyarakat di kelurahan sekip kecamatan lima puluh belum mengetahui ketentuan hukum mengenai perkawinan seperti akibat hukum perkawinan siri yang termasuk didalamnya mengenai waris dan status hukum anak dari perkawinan siri. Permasalahan yang mungkin timbul ketika masih ada warga yang melakukan perkawinan siri (tidak dicatatkan), kemudian timbul permasalahan mengenai hak waris ketika suami meninggal dunia dan hak harta bersama saat terjadi perceraian. Tidak tertutup kemungkinan akan dialami oleh masyarakat kelurahan sekip kecamatan lima puluh kota Pekanbaru. Metode pelaksanaan merupakan solusi yang ditawarkan untuk mengatasi masalah yang dihadapi mitra. Sesuai dengan persoalan prioritas yang dihadapi mitra sebagaimana telah disinggung maka metode pendekatan yang ditawarkan untuk menyelesaikan persoalan mitra adalah dengan metode ceramah dan tanya jawab. Hasil yang diperoleh dari kegiatan ini para peserta telah merasakan manfaatnya, yaitu mendapat tambahan pengetahuan dan pemahaman tentang akibat hukum perkawinan siri (tidak dicatatkan). Hal itu disimpulkan tim pengabdian kepada masyarakat setelah membandingkan hasil tes awal (pre test) dan tes akhir (post test) dengan cara mengajukan pertanyaan (kuesioner) sebelum dan sesudah pemberian materi. Hasil akurasi evaluasi yang dihasilkan mencapai 80\% pemahaman masyarakat meningkat setelah diberikan sosialisasi. Tujuan dari pelakasanaan sosialisasi ini adalah untuk meningkatkan pemahaman masyarakat kelurahan sekip mengenai akibat hukum perkawinan siri.
\end{abstract}

Kata kunci: Akibat, Hukum, Perkawinan Siri

\section{Abstract}

The analysis of the partner's situation illustrates the phenomenon that many people do not understand the legal consequences of unregistered marriages.Likewise, people in the Sekip sub-district, fifty sub-districts do not yet know the legal provisions regarding marriage, such as the legal consequences of unregistered marriages which include inheritance and the legal status of children from unregistered marriages.Problems that may arise when there are still residents who do unregistered marriages (not registered), then problems arise regarding inheritance rights when the husband dies and joint property rights when a divorce occurs. It is possible that the community of Sekip Village, Fifty District, Pekanbaru City will experience it. The implementation method is a solution offered to overcome the problems faced by partners. In accordance with the priority issues faced by partners as mentioned, the approach method offered to solve partner problems is the lecture and question and answer method.The results obtained from this activity the participants have felt the benefits, namely getting additional knowledge and understanding about the legal consequences of unregistered marriages (not recorded).It was concluded by the community service team after comparing the results of the initial test (pre test) and the final test (post test) by asking questions (questionnaires) before and after giving the material. The results of the resulting evaluation accuracy reached $80 \%$ public understanding increased after being given socialization. The purpose of this socialization is to increase the understanding of the Sekip village community regarding the legal consequences of unregistered marriages.

Keywords: Consequences, Law, Siri Marriage

\section{PENDAHULUAN}

Kelurahan Sekip adalah salah satu kelurahan yang maju perkembangan jumlah penduduknya di Kecamatan Lima Puluh. Letak yang strategis, karena berada didekat pusat kota Pekanbaru. menyebabkan kelurahan ini menjadi pilihan untuk berdomisili dan menjadi pilihan masyarakat juga untuk Membuka lapangan usaha. 
Berdasarkan wawancara awal tim pengabdian kepada tokoh masyarakat Kelurahan Sekip, jumlah generasi muda yang ada di kelurahan tersebut cukup banyak, rata-rata sudah mendekati usia perkawinan dan ada yang sudah melakukan perkawinan. Pelaksanaan perkawinan dapat terjadi antara sesama penduduk Kelurahan Sekip, maupun dengan warga diluar wilayah Kelurahan Sekip. Penduduk Kelurahan Sekip terdiri dari beragam suku dan juga dari etnis tionghoa.

Perkawinan merupakan aspek penting dalam kehidupan manusia karena hal tersebut memang mutlak terjadi pada makhluk hidup. Selain itu dalam hal perkawinan juga harus memperhatikan norma yang ada dimasyarakat karena perkawinan merupakan sebuah ikatan yang menyatukan antara laki-laki dan perempuan untuk membentuk suatu keluarga. Indonesia memiliki variasi dalam bentuk pelaksanaan perkawinannya. Mulai dari perkawinan melalui Kantor Urusan Agama (KUA), hingga perkawinan yang cukup dikenal oleh masyarakat dengan perkawinan bawah tangan atau perkawinan siri. Perkawinan yang tidak dicatatkan atau yang dikenal dengan istilah perkawinan siri yaitu perkawinan yang dilakukan dengan tidak dicatatkan di kantor pegawai pencatatan nikah. Bagi yang beragama Islam dicatatkan di Kantor Urusan Agama dan bagi yang beragama lain dicatatkan di Kantor Catatan Sipil.[1]

Permasalahan yang timbul adalah ketika akan melaksanakan perkawinan, masih banyak masyarakat yang melakukan perkawinan siri. Berdasarkan Pasal; 1 Undang-undang Nomor 1 tahun 1974 tentang Perkawinan menyebutkan perkawinan adalah ikatan lahir batin antara seorang pria dan seorang wanita sebagai suami istri dengan tujuan membentuk keluarga atau rumah tangga yang bahagia dan kekal berdasarkan Ketuhanan Yang Maha Esa.

Dengan adanya ikatan lahir batin antara pria dan wanita yang dibangun di atas nilai-nilai sakral karena berdasarkan Ketuhanan Yang Maha Esa yang merupakan sila pertama Pancasila. Maksudnya adalah bahwa perkawinan tidak cukup hanya dengan ikatan lahir atau ikatan batin saja, tetapi harus kedua-duanya, terjalinnya ikatan lahir batin merupakan fondasi dalam membentuk keluarga bahagia dan kekal.[2]

Di Indonesia perkawinan siri merupakan hal yang biasa terjadi. Peraturan Perundangundangan tidak mengatur menganai perkawinan siri. Perkawinan siri atau nikah di bawah tangan merupakan perkawinan yang dilakukan oleh masyarakat tanpa prosedur yang diatur di dalam Undang-Undang Nomor 1 Tahun 1974 tentang Perkawinan. Perkawinan siri dilaksanakan berdasarkan agama atau adat istiadat calon suami dan calon istri. Perkawinan siri tersebut sah secara agama atau adat.[3]. Sejak dilangsungkannya perkawinan, maka sejak saat itu menjadi tetaplah kedudukan laki-laki sebagai suami dan perempuan sebagai isteri, dan sejak saat itu pula suami dan isteri memperoleh hak-hak dan kewajibankewajiban tertentu dalam ikatan perkawinan.[4]

Pada Pasal 2 Undang-Undang No. 1 Tahun 1974 tentang Perkawinan dinyatakan bahwa perkawinan adalah sah apabila dilakukan menurut hukum masing-masing agamanya dan kepercayaannya. Berdasarkan ketentuan ini maka perkawinan adalah sah menurut ajaran agama dan juga sah menurut undang-undang perkawinan yang berlaku di Indonesia. Meskipun perkawinan siri merupakan perkawinan yang sah, perkawinan tersebut tetap harus dicatatkan. Pencatatan perkawinan merupakan aturan yang sifatnya administratif, dan tidak ada sanksi hukum bagi mereka yang tidak mencatatkan perkawinannya, hanya saja perkawinan yang tidak dicatatkan ini tidak mempunyai kekuatan hukum.

Momentum suatu perkawinan yang sah adalah apabila:

a. Telah dilangsungkan menurut hukum agama dan kepercayaan masing-masing.

b. Dicatat menurut peraturan perundang-undangan.

Perkawinan siri sangat merugikan bagi istri secara hukum. Perempuan tidak dianggap sebagai istri sah. Ia tidak berhak atas nafkah dan warisan dari suami jika ditinggal meninggal dunia. Selain itu sang istri tidak berhak atas harta gono-gini jika terjadi perceraian, karena secara hukum perkawinan tersebut dianggap tidak pernah terjadi. Seorang suami yang melakukan perkawinan siri dan tidak bertanggungjawab, mudah mengabaikan hak dan kewajibannya baik secara lahir maupun batin terhadap istri yang dinikahinya secara siri, karena tidak ada alat bukti berupa surat nikah, sebagai bukti autentik.[5] 
Selain itu, akibat hukum perkawinan siri juga terjadi pada kedudukan anak yang lahir dari perkawinan siri tersebut. Kejelasan status perkawinan suami isteri melalui bukti otentik tentang perkawinan mereka, menjadi landasan bagi kejelasan status hukum seorang anak. Seperti untuk kepengurusan akta kelahiran si anak, landasannya adalah surat nikah. Jika suami isteri tersebut tidak pernah mencatatkan perkawinannya, maka ketika lahir anak dan memerlukan akta kelahiran, kantor kependudukan tidak akan mengeluarkan akta kelahiran tersebut. Asal-usul seorang anak hanya dapat dibuktikan dengan akta kelahiran yang otentik yang dikeluarkan oleh pejabat yang berwenang atau oleh Pengadilan Negeri setelah melakukan pemeriksaan yang teliti atas permohonan yang bersangkutan (Pasal 55) anak yang sah adalah anak yang dilahirkan dalam atau sebagai akibat perkawinan yang sah. Perkawinan siri mengakibatkan kejelasan mengenai status anak tersebut akan hanya mempunyai hubungan perdata dengan ibunya dan keluarga ibunya saja. Kepastian hak dan kewajiban orang tua dan anak dari hasil perkawinan siri tidak dapat sepenuhnya dilindungi oleh Undang-Undang.[1]

Guna memaksimalkan perlindungan hukum bagai para pihak dalam perkawinan, dibutuhkan adanya kesadaran hukum. Di dalam ilmu hukum dikenal adanya beberapa pendapat tentang kesadaran hukum. Perihal kata atau pengertian kesadaran hukum, ada juga yang merumuskan bahwa sumber satu-satunya dari hukum dan kekuatan mengikatnya adalah kesadaran hukum dan keyakinan hukum individu di dalam masyarakat yang merupakan kesadaran hukum individu, merupakan pangkal dari pada kesadaran hukum masyarakat. [6]

Kesadaran hukum mempunyai beberapa konsepsi, salah satunya konsepsi mengenai kebudayaan hukum. Konsepsi ini mengandung ajaran ajaran kesadaran hukum lebih banyak mempermasalahkan kesadaran hukum yang dianggap sebagai mediator antara hukum dengan perilaku manusia, baik secara individual maupun kolektif.[7] Berdasarkan wawancara awal tim pengabdian kepada masyarakat, terdapat permasalahan yaitu masih adanya masyarakat Kelurahan Sekip, Kecamatan Lima Puluh Kota Pekanbaru yang belum memahami tentang akibat hukum perkawinan siri (tidak dicatatkan). Untuk itu berdasarkan hasil diskusi tim pengabdian masyarakat dan mitra didapatkan kebutuhan untuk diadakannya kegiatan pengabdian masyarakat yang diberi judul : "Peningkatan Pemahaman Masyarakat Terhadap Akibat Hukum Perkawinan Siri (Tidak Dicatatkan) Di Kelurahan Sekip Kecamatan Lima Puluh Kota Pekanbaru".

\section{METODE}

Metode pelaksanaan kegiatan pengabdian kepada masyarakat ini adalah dengan metode ceramah dan tanya jawab dalam rangka memberikan pengetahuan serta informasi kepada seluruh peserta yang mengikuti sosialisasi sehingga mereka bisa mengetahui akibat hukum perkawinan siri (tidak dicatatkan) seperti istri yang tidak berhak atas harta bersama ketika terjadi perceraian dan hak waris ketika suami meninggal dunia serta kedudukan hukum anak yang lahir dari perkawinan siri.

Rangkaian kegiatan yang dilaksanakan dalam rangka pengabdian kepada masyarakat menggunakan dua metode: Pertama, ceramah atau penyuluhan. Dalam metode ini penceramah atau penyuluh menyampaikan materi tentang akibat hukum perwakinan siri. Pada tahapan ini, peserta dibebaskan untuk bertanya jawab dengan penceramah. Rincian dari metode ini ialah pemaparan akibat hukum perkawinan siri, seperti istri yang tidak berhak atas harta bersama ketika terjadi perceraian dan hak waris ketika suami meninggal dunia serta kedudukan hukum anak yang lahir dari perkawinan siri.

Kedua, dialog interaktif, dalam tahapan ini peserta diposisikan sebagai subjek yang dapat memberikan ulasan terkait dengan problematika hukum mengenai perkawinan sebagaimana telah disinggung. Dialog ini sebagai curah pendapat peserta untuk memperoleh masukan berupa persoalan, aspirasi, usulan, gagasan dan solusi. Tim Pengabdian memberikan pre tes dan post tes kepada peserta untuk mengukur tingkat keberhasilan dalam pelaksanaan sosialisasi menegenai akibat hukum perkawinan siri(tidak dicatatkan) di kelurahan sekip kecamatan lima puluh kota pekanbaru. 


\section{HASIL DAN PEMBAHASAN}

\section{A. Hasil Kegiatan}

Hasil kegiatan pengabdian berupa evaluasi peningkatan pemahaman masyarakat kelurahan sekip kecamatan lima puluh kota Pekanbaru mengenai materi tentang akibat hukum perkawinan siri, seperti istri yang tidak berhak atas harta bersama ketika terjadi perceraian dan hak waris ketika suami meninggal dunia serta kedudukam hukum anak yang lahir dari perkawinan siri. Hasil evaluasi kegiatan menunjukkan bahwa peserta kegiatan pengabdian kepada masyarakat dapat memahami materi yang disampaikan oleh tim pengabdian masyarakat yang berasal dari Fakultas Hukum Universitas Lancang Kuning.

Indikator pemahaman mereka tercantum dalam hasil kuesioner yang diberikan pada saat kegiatan. Mereka memilih jawaban dalam kuesioner terdiri atas pilihan jawaban yang benar dan jawaban yang salah. Jawaban pada kuesioner terdapat dalam materi yang dibagikan dan materi yang disampaikan oleh tim pengabdian.

\section{B. Pembahasan \\ 1. Pelakasanaan Kegiatan}

Pelaksanaan penyuluhan menggunakan metode ceramah dan dialog. Sesi pertama menggunakan metode ceramah. Pemateri menyampaikan bahan/materi dalam bentuk paparan mengenai materi tentang akibat hukum perkawinan siri, seperti istri yang tidak berhak atas harta bersama ketika terjadi perceraian dan hak waris ketika suami meninggal dunia serta kedudukam hukum anak yang lahir dari perkawinan siri.

Peserta menyimak materi yang disampaikan pemateri. Namun, sebelum peserta diberikan materi, peserta diberikan kuesioner dengan beberapa pertanyaan mengenai materi tentang aspek tentang akibat hukum perkawinan siri sebagaimana telah disinggung.

Jawaban yang benar pada kuesioner itu terdapat materi yang disampaikan pemateri. Tujuan kuesioner diawal penyampaian materi ialah mengukur pengetahuan peserta. Pertanyaan pertama untuk mengukur pengetahuan peserta mengenai ketentuan hukum sahnya perkawinan, Bagaimanakah ketentuan sahnya sebuah perkawinan? Pilihan jawaban atas pertanyaan tersebut adalah (A) Perkawinan sah jika ada saksi (B) Perkawinan sah berdasarkan aturan dalam UU No. 1 Tahun 1974 Tentang Perkawinan. Peserta kegiatan yang menjawab jawaban yang benar, yaitu jawaban B adalah berjumlah 6 orang atau $35 \%$ dari jumlah peserta, sedangkan untuk jawaban A berjumlah 11 orang atau $65 \%$ dari jumlah peserta.

Pertanyaan kedua untuk mengukur pengetahuan perserta terkait kewajiban terhadap pencatatan perkawinan, yaitu apakah setiap perkawinan wajib melakukan proses pecatatan kepada petugas yang berwenang? Pilihan jawaban atas pertanyaan tersebut adalah (A) Wajib guna memperoleh kepastian hukum. (B)Tidak wajib karena perkawinan tetap sah dilakukan secara ketentuan agama. Peserta kegiatan yang menjawab jawaban yang benar, yaitu jawaban A adalah berjumlah 4 orang atau $23 \%$ dari jumlah peserta, sedangkan untuk jawaban B berjumlah 13 orang atau $77 \%$ dari jumlah peserta.

Pertanyaan ketiga untuk mengukur pengetahuan peserta mengenai hak istri apabila terjadi perceraian dari perawinan siri, yaitu apabila terjadi perceraian dari perkawinan siri, apakah istri berhak menuntut pembagian harta bersama selama perkawinan?. Pilihan jawaban atas pertanyaan tersebut adalah (A) Istri bisa menuntut hak atas harta bersama karena secara agama pernikahan itu sah. (B) Istri tidak berhak menuntut pembagian harta bersama karena secara hukum pernikahan itu tidak pernah ada. Peserta kegiatan yang menjawab jawaban yang benar, yaitu B adalah berjumlah 5 orang atau $30 \%$ dari jumlah peserta, sedangkan untuk jawaban B berjumlah 12 orang atau $70 \%$ dari jumlah peserta.

Pertanyaan kempat untuk mengukur pengetahuan peserta mengenai pembagian harta warisan dalam perkawinan siri, yaitu apabila dalam perkawinan siri, suami meninggal dunia dan meninggalkan harta warisan, apakah istri berhak atas harta warisan tersebut? Pilihan jawaban atas pertanyaan tersebut adalah (A) Istri tidak berhak atas harta warisan karena bukan merupakan istri yang sah secara hukum. (B) Istri berhak atas harta warisan karena merupakan istri yang sah secara agama. Peserta kegiatan yang menjawab jawaban benar yaitu A adalah 
berjumlah 4 orang atau $23 \%$ dari jumlah peserta, sedangkan untuk jawaban B berjumlah 13 orang atau $77 \%$ dari jumlah peserta.

Pertanyaan kelima untuk mengetahui pengetahuan peserta terhadap status hukum anak dari perkawinan siri, yaitu bagaimanakah status hukum seorang anak yang dilahirkan dari perkawinan siri? Pilihan jawaban atas pertanyaan tersebut adalah (A) Status anak merupakan anak sah karena lahir dari perkawinan yang sah menurut agama dan memiliki hubungan hukum dengan kedua orang tuanya. (B) Anak hanya memiliki hubungan hukum dengan ibunya saja. Peserta kegiatan yang menjawab jawaban benar, yaitu B adalah berjumlah 6 orang atau 35\% dari jumlah peserta, sedangkan untuk jawaban B berjumlah 11 orang atau $75 \%$ dari jumlah peserta.

Secara keseluruhan tingkat pengetahuan dan pemahaman peserta terhadap akibat hukum perkawinan siri masih rendah, masih banyak peserta yang belum memahami akibat hukum perkawinan siri, seperti istri yang tidak berhak atas harta bersama ketika terjadi perceraian dan hak waris ketika suami meninggal dunia serta kedudukam hukum anak yang lahir dari perkawinan siri.

Kegiatan ini dilaksanakan pada hari Kamis, 3 Juni 2021 di rumah salah satu masyarakat kelurahan sekip kecamatan lima puluh kota Pekanbaru. Kegiatan ini berhasil dengan tolak ukur sebagai berikut:

1. Jumlah peserta yang hadir berjumlah 17 orang dari 20 undangan peserta.

2. Kerjasama peserta dan tim pelaksana kegiatan berjalan lancar

3. Peserta kegiatan antusias mengikuti semua rangkaian penyuluhan mulai dari pemaparan materi hingga sesi tanya jawab.

Pada pelaksanaan kegiatan terjadi interaksi berupa tanya jawab antara tim pengabdian masyarakat dengan peserta. Salah satu peserta yang bertanya bernama bapak Erfan dengan pertanyaan, bagaimana upaya anak dari perkawinan siri untuk bisa mendapatkan hak waris dari ayahnya? Tim menjawab seorang anak yang lahir dari perkawinan siri (tidak dicatatkan) secara hukum agama dia tetaplah anak yang sah, namun secara hukum positif anak tersebut hanya memiliki hubungan keperdataan dengan ibunya saja.

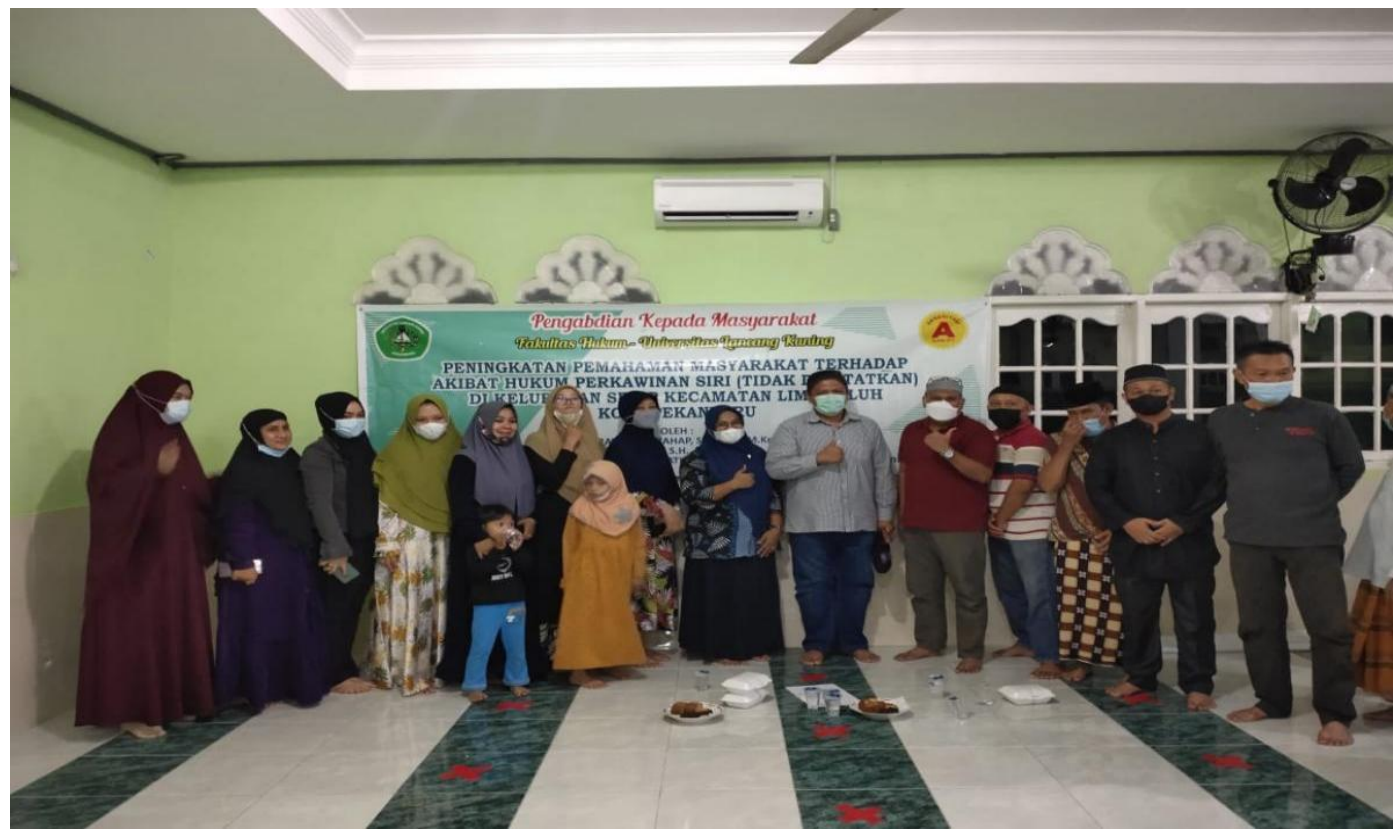

Gambar 1. Dokumentasi Pelaksanaan Kegiatan Pengabdian Kepada Masyarakat

Anak tidak memiliki hubungan hukum dengan ayahnya, karena secara hukum perkawinan tersebut dianggap tidak pernah ada. Upaya agar anak memiliki hubungan hukum dengan ayahnya, maka perlu dilakukan isbat nikah di pengadilan agama agar perkawinan tersebut dapat dicatatkan di kantor urusan agama. Sehingga perkawinan tersebut memiliki pembuktian dengan 
demikian secara otomatis anak tersebut memiliki kedudukan hukum yang jelas dengan kedua orang tuanya.

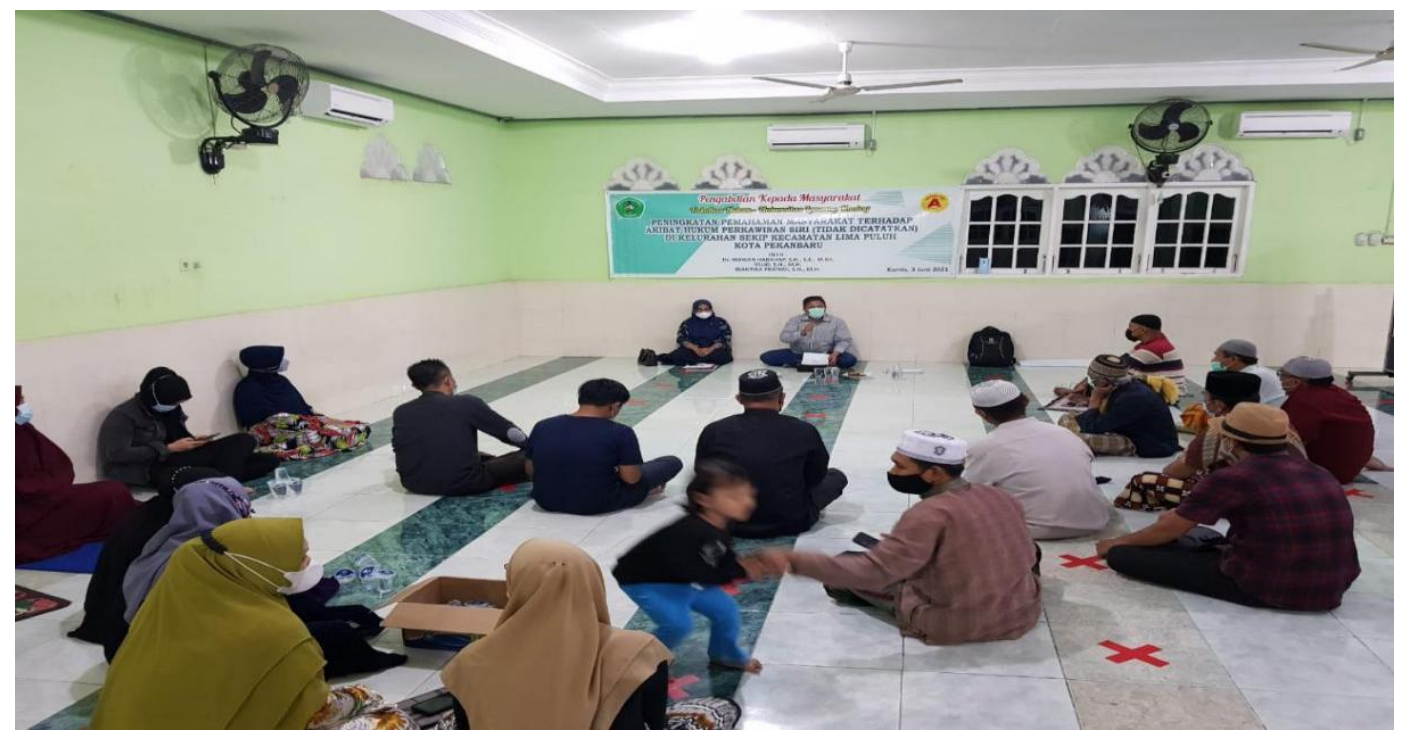

Gambar 2. Dokumentasi Khalayak Sasaran Mendengarkan Materi Penyuluhan.

\section{Evaluasi Kegiatan}

Evaluasi kegiatan pengabdian masyarakat menggunakan metode kuesioner/angket berjumlah dua puluh dua. Tim penyuluhan menyebar kuesioner kepada peserta dan peserta menjawab pertanyaan dalam kuesioner itu dengan cara melingkari jawaban yang benar. Tujuannya ialah untuk mengetahui peningkatan pemahaman peserta pada saat materi sebelum dan sesudah disampaikan.

Tabel 1. Jawaban Khalayak Sasaran Sesudah Pemberian Materi

\begin{tabular}{|c|l|c|c|}
\hline No & \multicolumn{1}{|c|}{ Pertanyaan } & \multicolumn{1}{|c|}{$\begin{array}{c}\text { Pilihan Jawaban } \\
\text { Jenaban }\end{array}$} & $\begin{array}{c}\text { Jawaban Kurang } \\
\text { Tepat }\end{array}$ \\
\hline 1. & $\begin{array}{l}\text { Bagaimanakah ketentuan hukum syarat sahnya } \\
\text { sebuah perkawinan? }\end{array}$ & $17(100 \%)$ & $0(0 \%)$ \\
\hline 2. & $\begin{array}{l}\text { Apakah setiap perkawinan wajib melakukan } \\
\text { proses pecatatan kepada petugas yang } \\
\text { berwenang? }\end{array}$ & $16(94 \%)$ & $1(6 \%)$ \\
\hline 3. & $\begin{array}{l}\text { Apabila terjadi perceraian dari perkawinan siri, } \\
\text { apakah istri berhak menuntut pembagian harta } \\
\text { bersama selama perkawinan? }\end{array}$ & $16(94 \%)$ & $1(6 \%)$ \\
\hline 4. & $\begin{array}{l}\text { Apabila dalam perkawinan siri, suami meninggal } \\
\text { dunia dan meninggalkan harta warisan, apakah } \\
\text { istri berhak atas harta warisan tersebut? }\end{array}$ & $15(88 \%)$ & $2(12 \%)$ \\
\hline 5. & $\begin{array}{l}\text { Bagaimanakah status hukum seorang anak yang } \\
\text { dilahirkan dari perkawinan siri? }\end{array}$ & $15(88 \%)$ & $2(12 \%)$ \\
\hline
\end{tabular}

Sumber: data primer diolah tahun 2021

Pemahaman mereka dapat dilihat pada setiap pertanyaan kuesioner sekaligus jawaban peserta. Kuesioner yang diberikan sebelum penyuluhan hukum, diberikan kembali kepada peserta kegiatan untuk diukur perbedaan sebelum dan sesudah kegiatan dilakukan. 
Setelah pemberian materi dan penyuluhan dilakukan, terjadi peningkatan pengetahuan peserta, hal ini dikarenakan peserta menyimak dengan baik materi yang diberikan pada saat penyuluhan, sehingga pada umumnya peserta pada saat menjawab kuisioener sudah mengetahui jawabannya sebagaimana dapat dilihat pada Tabel 1.

Berdasarkan Tabel 1, dapat dilihat bahwa pemahaman masyarakat kelurahan sekip kecamatan lima puluh kota Pekanbaru terhadap akibat hukum perkawinan siri (tidak dicatatkan), seperti istri yang tidak berhak atas harta bersama ketika terjadi perceraian dan hak waris ketika suami meninggal dunia serta kedudukan hukum anak yang lahir dari perkawinan siri meningkat setelah diberi pemahaman terhadap akibat hukum perkawinan siri (tidak dicatatkan)

\section{KESIMPULAN}

Berdasarkan uraian pembahasan di atas maka dapat disimpulkan bahwa, masyarakat kelurahan sekip kecamatan lima puluh kota Pekanbaru dapat memahami materi yang disampaikan oleh tim pengabdian. Indikator pemahaman mereka tercantum dalam hasil kuesioner yang diberikan pada saat kegiatan. Mereka memilih jawaban dalam kuesioner terdiri atas pilihan jawaban yang benar dan jawaban yang salah. Jawaban pada kuesioner terdapat dalam materi yang dibagikan dan materi yang disampaikan oleh tim pengabdian. Hasil evaluasi yang dilakukan mencapai $80 \%$ akurasi evaluasi tingkat pemahaman yang diberikan kepada masyarakat meningkat setelah diberikannya penyuluhan. Beberapa permasalahan dan keingintahuan yang dihadapi oleh peserta terkait materi tentang akibat hukum perkawinan siri, seperti istri yang tidak berhak atas harta bersama ketika terjadi perceraian dan hak waris ketika suami meninggal dunia serta kedudukan hukum anak yang lahir dari perkawinan siri dijawab dengan baik oleh tim pengabdian saat menyampaikan materi.

\section{UCAPAN TERIMA KASIH}

Penulis mengucapkan terima kasih kepada pihak yang telah berkontribusi dalam terlaksananya program pengabdian kepada masyarakat ini. Khususnya kepada Lurah Sekip Kecamatan Lima Puluh Kota Pekanbaru sebagai mitra pengabdian dan Fakultas Hukum Universitas Lancang Kuning Pekanbaru melalui Lembaga Penelitian dan Pengabdian Masyarakat dalam hal pendanaan kegiatan pengabdian kepada masyarakat.

\section{DAFTAR PUSTAKA}

[1] R. M. Kartina, "Akibat Hukum Terhadap Harta Kekayaan Yang Ditimbulkan Dari Perkawinan Siri Menurut Kompilasi Hukum Islam.," J. Syntax Idea, vol. 1, no. 6, p. 84, 2019.

[2] W. Saleh, Hukum Perkawinan Indonesia. Jakarta: Balai Pustaka, 1996.

[3] E. Agustina, "Akibat Hukum Hak Mewaris Anak Hasil Perkawinan Siri Berbasis Nilai Keadilan," J. Pembaharuan Huk., vol. 2, no. 2, p. 381, 2015.

[4] Z. Hamid, Pokok-Pokok Hukum Perkawinan Islam dan UU Perkawinan di Indonesia. Yogyakarta: Bina Cipta, 1976.

[5] S. U. Adillah, "Implikasi Hukum Dari Perkawinan Siri Terhadap Perempuan dan Anak," J. PALASTREN, vol. 7, no. 1, p. 204, 2014.

[6] S. Soekanto, Pengantar Penelitian Hukum. Jakarta: UI Press, 2008.

[7] S. Soekanto., Faktor-Faktor Yang Mempengaruhi Penegakan Hukum. Jakarta. Jakarta: Raja Grafindo, 2004. 